\title{
Buddhist Responses to State Control of Religion in China at the Century's Turn
}

\author{
SHI ZHIRU
}

We recall the fate of the Lung-hua Ssu [Longhua si], an ancient and famous monastery in the western suburb of the city of Shanghai. In pre-Republican days it enjoyed wide popularity, not only on account of its architecture but also of its beautiful surroundings. In the spring its courtyards were thronged with pilgrims and children who came to worship and to enjoy the many colored peach blossom [...] Then came the revolution of 1911 and with it the battalions of new soldiers in khaki uniforms. Some were dispatched to Shanghai for its protection. But there were no barracks and the government had no money to build them. Someone with a business mind, but little capacity for spiritual values, suggested that the commodious equipment of the [Longhua si] was available and the army could have it for a song, for the monks were powerless to resist. And so one morning soldiers came, turned out the monks, and established themselves there. That was eight years ago and the khaki-uniformed soldiers are still there. The droning voices of the bonzes in their chanting, the temple bells, and the footsteps of the pilgrims in spring time have all disappeared and in their place one hears the mingled notes of bugle and drum and their measured thud of soldiers' boots resounding in the yards as they practiced the goose-step to the rhythm of the "left-right" of the leader. A sight which one can hardly forget on entering the hall is to see, in place of the beautiful tapestries, candle sticks, kneeling stools, and burning lamps - the paraphernalia of worship and adoration - the entire floorspace crowded with stacks of rifles with shining bayonets, soldier-kits, and camp-beds - the paraphernalia of war and destruction. But in the center there remains the majestic image of Buddha, seated on a raised platform, with the serene and 
unperturbed face, looking down upon the strange sight with infinite pity for poor humanity thus gone astray. ${ }^{1}$

This passage describes the Longhua Monastery (Chin. Longhua si, "Dragon-flower Monastery") in the aftermath of the Revolution that established Republican China following the last Qing emperor Puyi's (1906-1967) abdication in February 1912. The author, Bishop Tsu, furnishes a fascinating glimpse of Buddhism in China during her transition to political modernization as the Qing imperial state finally crumpled under the weight of external foreign powers (the West and Japan) and internal civil uprisings to give birth to the Republic of China (1912-1949). Besides Longhua Monastery, other monasteries and temples possessing extensive facilities suffered similar plights during this era. ${ }^{2}$

As further evidence of heightened state intervention in religious activities, in 1915, the Republican Parliament headed by Yuan Shikai (r. 1912-1916) passed a bill titled "Regulations for the Control of Monasteries and Temples" (Chin. Guanli simiao tiaoli). Comprising thirty-one articles, the bill imposed state censure on ordination, public speaking, reception of guests, and even allowed the government to dismiss those abbots deemed to have violated monastic precepts. ${ }^{3}$ While the bill was actually in effect for too short a duration to have real impact in practice, it did index the mounting political pressures under which the sangha lived out their religious practices at the turn of the century. In other words, prior to the reli-

1 Tsu 1921, pp. 497-512.

2 Holmes Welch's $(1967,1968)$ works are still the best sources in English on this topic. Note that much of my information on Buddhism in this period is based on Welch (1968). His research suggested that revolutionary forces occupied Guangxiao monastery (Chin. Guangxiao si, in northern Jiangsu) and Jinshan monastery (Chin. Jinshan si, in Zhejiang) at different junctures in the Republican period. See Welch 1968, pp. 145-152. For a study in Chinese on Buddhism in this period, see Shi (1974). For a detailed study in Chinese on the modern Buddhist persecution, particularly in relation to state policies on monastery landholdings, see Huang 2006.

3 For a close analysis of these policies, see Huang 2006, pp. 208-254. Cf. Welch 1968, pp. 38-39 and 137-138. This bill was further revised in 1921 into a document of twenty-four articles titled "Revised Regulations for the Control of Monasteries and Temples" (Chin. Xiuzheng guanli simiao tiaoli). 
gious persecution that took place under Communist rule, Buddhists already felt a spiraling urgency as to the fate of their religion, given the historic transformations brought by the encounter with modernity.

The overwhelming sense of a growing Buddhist crisis engendered salient expressions of Buddhism during the Republican period that would be crucial for Buddhist survival under the threat of religious persecution during Communist rule. This paper analyzes two different kinds of Buddhist responses generated by a religious crisis that was profoundly embedded within the social and political restructuring of the state at the turn of the twentieth century. The modern Buddhist crisis really began with state violation of monastic property rights, and rapidly expanded to other areas of religious life like the rights to ordination, to perform particular religious services, and ultimately to practice the religion. This paper thus contributes to the understanding of "Buddhist Approaches to Human Rights" (the theme of this volume) by discussing an important facet of human rights, namely, religious rights. It examines the different paradigms religious leaders undertook during the Qing-Republican transition as measures to protect Buddhist rights against antireligious state policies and to ward off the possible extinction of their religion in the encounter with modernity. While the two Buddhist paradigms appear, on the surface, to be dichotomized, there really exist significant overlaps and a certain degree of fluidity between them, so that it is more useful to see them as prominent tendencies in a continuum, rather than sharply demarcated polarities. During this critical phase Buddhist leaders came forward to sow the seeds for formative visions of Buddhism that have continued today to inspire the practices of Chinese Buddhist communities outside China, most prominently in Taiwan, as well as the current resurgence of Buddhism in mainland China. ${ }^{4}$

\section{Buddhism and State Relations}

As already indicated, the modern Chinese Buddhist crisis really began with state confiscation and borrowing of monastic land, the full impact of which can only be understood against the long his-

4 On the current resurgence of Buddhism in mainland China, see Zhe 2004. 
tory of Buddhist institutional dependence on the imperial court and state for patronage and protection to ensure its prosperity. In India, the religious vocation was privileged as a sphere beyond secular law and rule so that all religious institutions were naturally exempted from taxation, criminal law, or paying obeisance to the ruler and his court. Arriving in China at the turn of the Common Era, the practices and assumptions of Indian Buddhist monasticism immediately ran headlong against a different concept of religiopolitical rulership: for the Chinese people and the predominantly Confucian court members, their sovereign (or monarch) was the "Son of Heaven" (Chin. tianzi) whose political rule was divinely mandated by Heaven (Chin. tianming), so that the ruler naturally commanded respect from all classes of people, even religious clerics. The clash of Buddhist practices with Sinitic political ideology is particularly documented in a court petition titled "Treatise On Why The Monk Need Not Bow To The Ruler" (Chin. Shamen bujing wangzhe lun), composed in 404 by the aristocratic, learned monk Huiyuan (334-416). ${ }^{5}$

To facilitate state vigilance over Buddhist activities, a hierarchy of monastic officials was introduced during the Northern Wei rule (386-585), which perpetuated through the centuries with occasional revisions until the Qing period (1644-1912). ${ }^{6}$ State sangha officials administered a range of religious affairs such as the dispensing of ordination certificates, the registration of monasteries, temples, and monks, as well as the issuance of travel permits for monastic travel, all of which were conduits for policing and limiting religion. With state control the religion also received patronage and protection. From time to time, the state also took steps to downsize, and even confiscate, properties belonging to Buddhist monasteries and temples, often redirecting the assets to state use in order to curb the growth of the Buddhist institution. Throughout Chinese history, the state powers oscillated between a deep-rooted paranoia of Bud-

5 The Shamen bujing wangzhe lun is collected in the "Records to Propagate and Clarify (the Teachings)" (Chin. Hongming ji), compiled by Sengyou (445-518); see T. 2102: 52.1a-95b. For an English translation of this treatise, see Hurvitz 1957, pp. 2-36. For further discussion of its role in church-state relations of the early medieval period, see Zürcher 1972, pp. 231-239. For a study of modern developments, see Zhe 2004.

6 For a study of the sangha official institution, see Shi 1981. 
dhism as a breeding ground for sedentary movements and parasite on the state's resources, on the one hand, and on the other, an equally strong desire to endorse Buddhist activities, if only to secure spiritual protection for the state's prosperity and the ruler's welfare.

While state patronage was certainly one of the reasons for the flourishing of Buddhism in China, it also inevitably placed the monastic establishment at the mercy of state policies that often operated against its favor. The most important examples are indubitably the Four Buddhist Persecutions, which were wholesale suppression of Buddhists carried out on four occasions from the fifth through the tenth century by four Chinese emperors. Later Buddhist historians called them "The Buddhist Persecutions by the Three [Emperors] $\mathrm{Wu}$ and the One [Emperor] Zong" (Chin. sanwu yizong fa'nan), named after the emperors who decreed the persecutions. ${ }^{7}$ A variety of factors contributed to these persecutions of Buddhists, among which were economic reasons (fear of the growing power of the Buddhist monasteries, or a perceived need to strengthen the state monetary and land assets), as well as anti-Buddhist sentiments incited by religious rivalry, especially from the other two great traditions, religious Daoism and Confucianism. Very often, the antiBuddhist measures, couched in phrases like "to abolish Buddhism" (Chin. fei fo) or "to exterminate Buddhism" (Chin. mie fo), included the destruction of Buddhist texts, Buddha images, and a forced laicization of the monastic community that was intended to reduce the Buddhist population, sometimes simply to acquire more labor or military resources for the state. Consequently, for Chinese Bud-

7 Historians refer to these infamous persecutions as the "Four Great Buddhist Persecutions" (Chin. si da fa'nan or sanwu yizong fa'nan). Zhipan (fl. 1258-1269) discusses the persecutions in his work "Genealogy Record of Buddha Patriachs" (Chin. Fozu tongji), T. 2035: 49.392-393. The first three persecutions were decreed by emperors with the name of Wu: first in 446-452 by emperor Wudi of Northern Wei; the second in 573-578 by emperor Wudi of Northern Zhou; the third in $845-847$ by emperor Wuzong of Tang Dynasty. The fourth persecution happened in 955 during the reign of emperor Shizong of Latter Zhou during the Five Dynasties. As J.J.M. de Groot (1903, vol. 1, p. 16) has pointed out in his classic study of sectarianism and religious persecutions in China, "Buddhism has always had much more to suffer from the anathema of the State than Daoism". 
dhists, a religious crisis was incontrovertibly bound to adversarial political circumstances and state persecution.

Another related concept was the neologism "Final Dharma" (Chin. mofa), which describes the demise of Buddhist teachings in an era when the Buddha had long since entered nirvanna and all semblances of the monastic community had disappeared. According to modern scholarship, while references to the decline of Buddhism were present in Indian literature, the systematization of this decline into a threefold periodization - "Correct Teachings" (Chin. zhengfa), "Counterfeit Teachings" (Chin. xiangfa) and "Final Teachings" (Chin. mofa) - particularly the final phase of mofa - was most likely articulated in medieval China, particularly the final phase, mofa. 8 These teachings of the decline of Buddhism were prompted no doubt by an overwhelming spiritual urgency felt by early medieval Buddhists who suffered and mourned the deplorable destruction the consecutive state persecutions brought to their religion.

Strictly speaking, the persecution of Buddhists in modern China in the sense of fa'nan (like the "Four Buddhist Persecutions" in the medieval period) only happened during Communist rule. But prior to this, waves of land confiscation by the state as well as spreading socio-political instability in the face of modernism and external threats from the West and Japan already augmented the crescendo which culminated in scenes of mass religious persecution. In the name of Cultural Revolution the Communist government, convinced that "religion is opium," took on massive antireligious measures: not only did they destroyed Buddhist architecture, images, and texts, they further implemented land reforms to abolish monastic ownership of land, and reinforced the laicization of monks and nuns.

8 In the translations of sütras by the Central Asian monk Dharmarakșa, the term "Final Age" (Chin. moshi) is used to translate the Sanskrit word paścimakāla which means "latter age". However, the term "Final dharma" (Chin. mofa) does not occur in these translations of Indian works. Hence modern scholarship argues that the concept mofa was most likely coined in China in response particularly to the massive state persecutions. On the appearance of the term mofa, see Nattier 1991; Hubbard 1996. 


\section{From Land Confiscation to Antireligious Measures}

State expropriation of monasteries and landholdings were to definitively shape the Buddhist crisis, and the Buddhist responses discussed later are in fact originally linked to the threat of the state seizure of monasteries and landholdings. Land confiscation actually began in the waning years of the Qing dynasty (1644-1912). In 1898, a proposal to the Qing court composed by the Hunan Province governor-general Zhang Zhidong (1837-1909), titled "Essay on Exhortation to Learning" (Chin. Quanxue pian), argued for governmental confiscation of up to seventy per cent of landholdings and assets belonging to Buddhist and Daoist monasteries for state educational reform. ${ }^{9}$ The court adopted the proposal and pronounced a decree permitting local authorities to convert into "schools" (Chin. xuetang) those temples that no longer performed ancestral rites. Records suggest that religious sites were deployed for setting up not only modern schools, but factories as well. Although this decree was briefly retracted in 1905, the policy was reinstated later in the same year when official abolition of the civil examination meant local authorities had to bear the institutional and monetary provisions for public education in a rapidly dwindling state economy..$^{10}$ Again, religious sites with extensive landholdings and vacant architecture invited preying eyes! This state violation of religious rights to properties and land ownership must have greatly alarmed the monastic communities, since it would have signaled to them that the government increasingly viewed Buddhism as possessing negligible social utility in a modern world. In

9 Zhang basically echoed sentiments that were already voiced by others, for example Kang Youwei. Zhang's contribution was to work out a precise calculation of the distribution of income, proposing that seven out of ten "Buddhist monasteries" (Chin. fosi) and "Daoist temples" (Chin. daoguan) should be turned into modern "learning academies" (Chin. xuetang), with seven tenths of the income from their agricultural fields redirected to subsidize the costs of running the schools. The monks should be left with only three tenths of their landed income. See Huang 2006, pp. 75-132.

10 For example, in his biography, the monk Xuyun registered a wave of confiscation of Buddhist monasteries during the winter of 19051906 (Luk 1988, p. 67). 
fact its extensive landholdings and assets might have seem to impede the modernizing of Chinese society since they occupied badly needed ground space and resources for building public economic and social institutions, or modern transportation. Qing-Republican Buddhist leaders would have felt particularly dismayed given that these land and asset troubles were coming on the heels of the repeated blows Buddhism recently suffered from the widespread civil rebellions against Qing rule, the most severe of which was the Taiping rebellion (1850-1864), a millenarian movement which ingeniously amalgamated traditional Chinese eschatology with Christian messianism. ${ }^{11}$

When the revolutionary armies entered the scene in 1911, the military seizure of monastic buildings and landholdings described by Bishop Tsu became all too common and perpetuated throughout the Republican era (1912-1949). After the founding of the Republic warfare did not cease. Instead, the nation was plunged into consecutive wars: further revolutions, the return of Warlords, the SinoJapanese War (1927-1937), and the Chinese Civil War (that is, the Nationalist-Communist War, 1927-1950) with the Communists emerging as the final victors who founded the People's Republic of China in 1949. All through the Republican Era, confiscation or borrowing of Buddhist properties was widespread, especially in the outlying provinces, notably in Canton (Guangdong Province), the seat of revolutionary thought, where Sun Zhongshan (1866-1925, also known as Sun Yat-sen) urgently needed resources to fortify and maintain his troops. Moreover, Sun's accomplices and followers, who were frequently antireligious in outlook, were especially fervent in stamping out superstition. One description of the situation in Guangdong tells us:

In the ensuring years most of the large monasteries and small temples of the city were confiscated, sold, or demolished. Heavy taxes were imposed

11 The Taiping rebellion was headed by Hong Xiuquan (1813-1864), a frustrated scholar of the Hakka minority who repeatedly failed the imperial examinations. Converting to Christianity, he had visions of himself as the younger brother of Jesus Christ and formed a religious movement, an ad hoc mixture of indigenous Chinese eschatology and Christian salvation, and soon after put together an army to challenge Qing rule. 
on the fees charged by monks for mortuary rites and even on the tinfoil used in making the paper images that were burned for the benefit of the deceased. These antireligious levies became so pervasive that in 1924 an Italian flag was seen on a paper automobile to save it from confiscation in hell. The government was indifferent to religious sensibilities. For example, in order to free land for agriculture, a mass exhumation of graves was ordered in the countryside around [Guangdong Province]. Despite the popular reluctance to disturb ancestral bones, this was ruthlessly carried out. ${ }^{12}$

As the revolution army marched northward to take over the rest of China, the troops continued on this path of destroying religious culture wherever they went. Monasteries were demolished; "idol" images were smashed; and religious buildings and land were seized to make way for schools, police stations, agricultural projects, or other public welfare establishments.

In 1928, the first Society to Abolish Superstition was established in Beijing, and soon after, similar societies appeared in Zhejiang, all of which had the agenda to cause the government to laicize the monastics, abolish Buddhist rites for the dead, and ban the use of talismans, amulets, and such type of "superstitious" objects. ${ }^{13}$ Factionalism occurred in the revolutionary army that resulted in the expulsion of the Communists by the conservative strand in the Nationalist government. Although the surge to suppress superstition gave way in 1929 to policies of religious tolerance and protection of religious architecture, destruction and infringement of Buddhist properties and images persisted in those regions outside Nationalist rule. Moreover, the Sino-Japanese War (1927-1937) brought yet another tide of large-scale destruction throughout the country. Metal images were melted down to make bullets; Buddhist monasteries and lands were again borrowed by the state for various administration or military purposes. For example, the Longhua monastery, in Bishop Tsu's description, remained in the hands of one batch of troops or the other until the end of the Sino-Japanese War. The Jinshan Monastery (Chin. Jinshan si, "Golden Mountain Monastery"), a renowned Buddhist monastery in Zhejiang, was evidently occupied by Nationalist troops who even used the facilities to house Japanese prisoners at one juncture. ${ }^{14}$ Monasteries and temples were also ravaged

12 Welch 1968, pp. 147-148.

13 Ibid., p. 151.

14 Ibid, p. 145. 
by the wars. Japanese bombing particularly targeted and inflicted severe damage upon religious buildings that were converted for state purposes.

Under imperial rule, the Buddhist communities had enjoyed state protection while subjecting itself to state regulation. However, with the birth of modern China in the Republican Era, absence of state protection critically undermined the stability of the religion. Under Nationalist rule, the government repeatedly issued policies (for example, 1931, 1936, and 1946) to ensure some degree of protection for Buddhist monasteries, especially against the frequent land encroachment by local authorities or sometimes even selfish abbots. Moreover in 1930, 1935, and 1946, the government passed a law to prevent local authorities from levying taxes on the performance of Buddhist rites for the dead. Despite these state laws, the actual situation was usually more in the hands of the local authorities since the centralized government was undermined by the incessant warfare of that period. Local officials were faced with the real pressure of finding space to set up schools and other public institutions in their areas, very often with minimal assistance from the central government; hence they frequently chose to ignore the revised policies and continued the borrowing and confiscating of monastic properties for public use.

In short, the Buddhist communities in the Republican period faced a religious crisis that included state encroachment on monastic properties, threats of laicization and persecution, all of which were compounded by the ravages of incessant warfare. While violation of property and religious rights are not yet as serious as they would become during the Cultural Revolution under the Communist rule, the Republican Buddhist leaders must have felt a profound urgency to locate means to ascertain the survival of their religion in the changing circumstances of modernity. Throughout this period, China endured intense political turmoil, social conflict, and cultural clashes. In the late Qing period, the expansive presences of Western and Japanese powers already signaled the tides against the collapsing imperial authorities.

As Western economics, knowledge, rationality, and science infiltrated Chinese society, China had to rapidly redefine itself in a modernizing world after centuries of deep entrenchment in the traditional cultural, ideological, and social practices of imperial rule. Exhortations to transform "an Old China" into "a New China" echoed throughout intellectual, literary, and political discourse, as leaders 
emerged in multiple spheres to articulate new visions of a progressive China which would assume a critical role on the global landscape, while still preserving its traditional strengths. In this fermenting environment, one controversy that was repeatedly debated was the place of religion in modern China. Revolutionary thought in general, particularly pro-Marxist thought, tended to see religion as superstition or even opium that ultimately numbs the faculty of rational discrimination. Nonetheless, during the Qing-Republican transition, Chinese intellectuals like Kang Youwei (1858-1927), Liang Qichao (1873-1929), and Tan Sitong (1865-1898) remained partial to Buddhist thought, considering it to be more favorably disposed to modern, objective rationality while possessing Asian habits of mental cultivation and moral behaviour. ${ }^{15}$ For several thinkers, given Buddhism's long history in China and (for them) its relative compatibility with modern society (over and against Christianity, the religion of the West), it had true potential to become the unique Chinese contribution to global cultural and intellectual conversations in a modern world.

\section{Buddhist Responses: Progressive Intellectuals and Modernist Visions}

In response to the tenuous intellectual and political climates, there arose in Qing-Republican period a cluster of lay and monastic advocates for reforming and modernizing Buddhism for a "New China". To a greater or lesser extent these leaders readily incorporated modernist tendencies, frequently Western elements, into their visions of a new Buddhism. Among the laymen the most representative is Yang Wenhui (1837-1911), who spearheaded the "Jinling Sūtra Publishing House" (Chin. Jinling kejing chu), and also brought back from Japan three hundred sütra texts which had been lost in China. ${ }^{16}$ In addition, he was very active in establishing centers for modern studies of Buddhist texts, such as the "Jetavana Hermitage" (Chin. Zhihuan jingshe) built in 1908 at the site of his Publishing House and the "Buddhist Research Society" (Chin. Foxue yanjiu hui) founded in 1910. Yang was therefore a pivotal figure in the beginnings of modern Buddhist studies in China, and his centers of modern Buddhist

15 Chan 1985, pp. 37-49; Pittman 2001, pp. 67-68.

16 For Yang Wenhui's biography and work, see Lou 1996; Zhang 2004. 
learning attracted students who would become major thinkers in modern Chinese intellectual history like Zhang Taiyan (1868-1936), Tan Sitong, and the reformist monk Taixu (1890-1947). ${ }^{17}$ On account of Yang's Buddhist publishing and learning enterprises, major figures in the intellectual and political thought came into contact with Buddhist philosophy. A resurgence in the study of Chinese Yogācāra, including interest in comparing the Buddhist Mind-Only teachings with Western philosophy of Idealism, documents the intellectual creativity and energy that arose from Buddhist efforts to find a place for the religion in a volatile intellectual and sociopolitical environment. Comparative efforts to align Buddhist thought with science also occurred as part of this type of intellectual endeavors. These publishing missions and study groups kept alive and even reinvigorated Buddhist intellectual history during the challenging times.

Among the monks who advocated reforms, a group of revolutionary monks appeared during the late Qing who supported the anti-imperial sentiments and joined the revolutionary forces, much to the chagrin of the Buddhist orthodoxy. This circle of monks were versed in the so-called "new learning" of the time, particularly the political writings of modern Chinese intellectuals like Kang Youwei, Liang Qichao, Tan Sitong, and Zhang Taiyan, and even Chinese translations of Western writings such as Yan Fu's (1854-1921) translations of Thomas Huxley's Evolution and Ethics, Adam Smith's Weath of Nations, John Stuart Mill's On Liberty, and Herbert Spencer's Study of Sociology ${ }^{18}$ However, this phenomenon was ac-

17 For all these reasons, Yang Wenhui has been frequently hailed as the "Father of the Modern Buddhist Renaissance". On Buddhism in intellectual circles and the political thought of the Qing period, see Chan 1985.

18 Yan Fu was a Chinese scholar and translator who studied at the Fuzhou Navy Administration Academy (Chin. Fuzhou chuanzheng xuetang) in Fuzhou at Fujian Province. He also spent two years (1877-1879) studying at the Navy Academy in Greenwich, England. After 1896, he supervised several translation institutes operating under central and local government authority, and following the fall of the Qing dynasty in 1911, he was appointed president of the Capital Municipal University, later known as the University of Beijing. For a study of Yan Fu, see Schwartz 1964. 
tually short-lived. More lasting contributions would come from the monastic reformers who envisioned new expressions of Buddhism, particularly institutional changes, to ensure that Buddhism did not become outmoded and irrelevant within the emerging "New China" in a new world order. Among these figures is the activist and reformer monk, Taixu from Zhejiang, one of Yang's students at the Jetavana Hermitage. ${ }^{19}$ In his early days as a monk, Taixu joined the activities of the revolutionary monks and for a time held a firm conviction that anarchism was compatible with Buddhism and should be implemented as the political system for the emerging "New China". ${ }^{20}$ Reading Tan Sitong's "Learning of Benevolence" (Chin. Renxue), Taixu was persuaded that the world must rely on "Buddhist learning" (Chin. foxue) for its liberation; thereon he dedicated himself to a lifelong cause of reforming Buddhism "to save the world" (Chin. jiu shi). ${ }^{21} \mathrm{He}$ would in time became disillusioned with political revolutionary thought, and after three years of "secluded retreat" (Chin. biguan) at Mount Putuo, reemerged to propound Buddhist reforms across the spheres of doctrine, education, and institution in order to prevent Buddhism from the fate of becoming obsolete at the dawn of modernity in China. ${ }^{22}$

Taixu and other reformer monks all had to address the intellectual, institutional, and political problems that Buddhism encoun-

19 Among the works in English on Taixu, the most important is a book-length monograph by Pittman 2001. For a study in Chinese, see Guo 1996.

20 Yinshun 1998, vol. 29, p. 194. Also see Jiang (1993) for his discussion of Taixu's early days. The most popular standard source for Taixu's life is the biography compiled by Yinshun (1950).

21 Taixu, for instance, declared: "At that time I firmly believed that my accomplishments in Buddhism together with the 'new' knowledge would be adequate for me to save the world. The next year Master Eight Fingers and I worked on the Sangha Education Association." (Yinshun 1998, vol. 21, p. 348). Taixu (1978, pp. 115-125) also delivered a lecture titled "The Spirit of Salvation in Buddhist Teachings" (Fofa jiushi zhi jingshen). For an English translation of the Renxue, see Chan 1984.

22 Unable to win the Buddhist community over to his ideas, and further devastated by the outbreak of the First World War and the war-torn state of China, Taixu retreated in October 1914 to Mount Putuo where he remained for three years in self-imposed reclusion. 
tered during the Qing-Republican period. Institutional and educational reforms were particularly key components that very often were really introduced first as counter measures to state expropriation of Buddhist properties. The "public monasteries" (Chin. conglin) drew up four strategies to halt the government from seizing monastic land to set up secular education: (1) voluntary provision of funds and space to reduce the extent of confiscation; (2) establishing secular schools of their own initiative in the hope of diverting confiscation; (3) implementing schools for monastic education, including those created with the help of Japanese missionaries; (4) provision of funds and space for a secular school, while sending monks to Japan to learn Japanese monastic education in preparation for setting up their own monastic schools. ${ }^{23}$

Up to the Qing period, monastic education had been fairly loosely conceived, and the study of Buddhist texts was really built around a tradition of apprenticeship where younger monks would learn "sütra lecturing" (Chin. jiang jing) from a senior, experienced monk. ${ }^{24}$ Buddhist teachers traditionally specialized in one or more Buddhist sütras, or a particular set of Buddhist literature like the vinaya, the code of monastic discipline. In this format the agenda was to train and prepare preachers for proselytizing and lecturing on sūtras to lay and monastic audiences. The aspirant usually sought out eminent masters for teachings, or went for intensive training at renowned monastic centers. Young monastics aspiring to teach would travel from site to site to listen to sermon expositions by eminent specialists and study under them. The modern "Buddhist seminary" (Chin. foxue yuan) with a fairly comprehensive curriculum that taught foreign languages and secular subjects was thus really an invention of this period; it was conceived as part of a re-

23 Huang 1991, pp. 300-301. For example, in 1904, the Japanese Buddhists Mizuno Baigyō and Itō Kendō helped the Kaifu Monastery (Chin. Kaifu si) in Changsha (Hunan Province) to set up the "Sangha Normal School" (Chin. Seng shifan xuetang), which was structured after Japanese Buddhist schools. Another similar school, also based on the Japanese model although not explicitly affiliated with Japanese missionaries, is the "Normal Sangha School" (Chin. Putong seng xuetang) at Tianning Monastery (Chin. Tianning si) in Yangzhou. See Huang 2006, pp. 101-121; Welch 1968, p. 13.

24 For a more detailed description of this traditional system of training Buddhist preachers, see Welch 1968, pp. 105-109. 
structuring of sangha training under the influence of Western and Japanese models of public education. This new educational system was designed to train monks to spread the faith, to fortify a lay Buddhist movement, and also to persuade a broader audience that Buddhism was a component of Chinese culture worth preserving. The re-visioning of monastic education included physical renovation: the monasteries installed modern facilities for the seminary, often fashioned after the Western classroom with chalkboards, chairs, and tables. In many ways, the new sanigha schools could be traced to the kind of "new" Buddhist education introduced by Yang Wenhui at his Jetavana Hermitage, and resonated with the kind of new secular schools associated with the modern educational reforms that arose following the disintegration of the traditional imperial system.

Taixu strongly argued for revolutionizing sangha education and introduced educational reforms to radically revise the curricular and organizational structures of monastic learning. ${ }^{25}$ As part of these grand schemes of educational reform, he proposed reducing the size of the monastic population, the number of which he continuously adjusted over the years. By 1930, he proposed the ideal size to be twenty thousand, five thousand of whom would be students, with twelve thousand bodhisattva monastics and three thousand elders. ${ }^{26} \mathrm{He}$ designated specific roles to the bodhisattva monastics: five thousand to propagate Buddhism through public preaching and teaching; three thousand to serve as administrators in Buddhist educational institutions; fifteen hundred to engage in Buddhist charitable and relief work; fifteen hundred to serve as instructors in the monastic educational system; and one thousand to participate in various cultural affairs. Moreover, Taixu envisioned a sangha-operated nationwide system of Buddhist schools to replace the secular education that was taking shape in modern China. He mapped out a statistical distribution of schools of different grades for counties and provinces, ranging from a Buddhist primary school in each county to a Buddhist university in every three

25 Taixu's own writings on monastic educational reforms are mostly collected in vol. 9 of "Complete Writings of Master Taixu" (Chin. Taixu dashi quanshu). For a discussion of the background to Taixu's proposed reforms on Buddhist education, see Jiang 1998, pp. 439471. For a treatment in English, see Pittman 2001, pp. 229-236.

26 Yinshun 1998, vol. 9, p. 479. 
provinces. ${ }^{27}$ The precise specification of statistical and geographical distribution, as well as the occupational roles, most likely imitated the style of proposals for reforms in secular education like Zhang Zhidong's "Essay on Exhortation to Learning" which was mentioned earlier.

Furthermore, in order to combat state infringement on religious rights, the Buddhist monasteries, which until the Qing period had stayed fairly independent of each other, rallied together to form national associations as a forum to lobby against detrimental government policies. Early in his career, while he was still in the company of revolutionary monks, Taixu was already involved in forming the "Sangha Education Association" (Chin. Seng[qie] jiaoyu hui), which promoted systematic education for the monastics. ${ }^{28}$ After the founding of the Republic of China, Taixu and other progressive monks attempted to set up the "Association for the Advancement of Buddhism" (Chin. Fojiao xiejin hui) with plans to make the wellendowed Jinshan Monastery its headquarters and to set up a modern monastic school as part of sangha educational reform. ${ }^{29}$ These plans were made on the socialist assumption that monastic properties and landholdings should be considered the common property of all Buddhists, and should therefore be employed for the public welfare and for the education of Buddhist communities. However, the residential monastic community at Jinshan saw Taixu and his affiliates as staging an illegal seizure of their monastic landholdings, reminiscent of the hostile military and government officials' actions, so they rioted against what they took to be an intrusion on their property rights. ${ }^{30}$ Taixu commented on the failure:

The Association's charter did contain the socialist revolutionary notion of using Buddhist property to operate a public Buddhist enterprise but it was supposed to be a peaceful, progressive step. ${ }^{31}$

27 Taixu 1998, vol. 9, pp. 481-482.

28 Yinshun 1998, vol. 21, pp. 348.

29 For Taixu's views on national Buddhist associations, see his essays (Yinshun 1998, vol. 9, p. 328-459). For a general discussion of the role of Buddhist associations, see Welch 1968, p. 26-27.

30 On the Jinshan incident, see Jiang 1993, p. 114; Pittman 2001, pp. 7477; Welch 1968, pp. 33-34.

31 Yinshun 1998, vol. 29, p. 201. 
This incident earned Taixu the implacable ire of the conservatives among the Buddhist ecclesiastics. Besides this Jinshan incident, there were several other attempts to establish national Buddhist associations but it was not until 1912 that a "Chinese Buddhist Federation Association" (Chin. Zhonghua fojiao zonghui) was successfully formed which collaborated with Sun Zhongshan's government. ${ }^{32}$

Taixu's doctrinal reforms tackled yet another major criticism of Buddhism in this period - the accusation that Buddhists, rather than engaging actively with the living world, were preoccupied with only the realm of the dead. Revolutionary and Communist leaders often frowned on ritual and images as "superstition" which ought to be eradicated. Reformist Buddhists reacted by sharply demarcating a true Buddhist core from a degenerate, ritual Buddhism, in a manner parallel to the Lutheran reforms in the history of Christianity which distinguished a text-based Protestantism from a ritual-centered Catholicism. Taixu, for instance, argued that over the course of its history in China, Buddhism lost its original purpose and became inextricably associated with death and afterlife rites, particularly preparation for rebirth in the Western Pure Land of Amitābha Buddha. Just as the intellectual, political, and social orders in China had to rearticulate themselves for a new era, Buddhism would need to revolutionize in order to retain critical roles in a "New China". Toward this goal, Taixu introduced "Buddhism for the Human Life," a teaching designed to re-orientate the locus of Buddhism away from death and the afterlife to the living world of human society. ${ }^{33}$

A cornerstone in Taixu's doctrinal framework is his interpretation of the "Human Vehicle" (Chin. rensheng) for modern society. He adopted the traditional division of Buddhist history into three periods, to which he then assigned different teachings and practices.

32 Yinshun 1998., p. 203; vol. 26, p. 260.

33 On rensheng fojiao, see Taixu's 1928 lecture "Discourse on Buddhism for Human Life" (Chin. "Rensheng fojiao de shuoming") in Yinshun 1998, vol. 2, pp. 205-216; also his 1946 lecture "Buddhism for Human Life" (Chin. "Rensheng de fojiao"; Yinshun 1998, vol. 2, pp. 238-242). 
- During the period of the "True dharma" (Chin. zhengfa), one relies on the practices and attainments of the "Hearers' Vehicle" (Skr. śravvaka, Chin. shengwen sheng) to progress to the "Great Vehicle" (Skr. Mahāyāna, Chin. dasheng).

- During the period of the "Counterfeit dharma" (Chin. xiangfa), one relies on the practices and attainments of the "Heavenly or Deva Vehicle" (Chin. tian sheng) to progress to the "Great Vehicle".

- During the period of the "Final dharma" (Chin. mofa), one relies on the practices and attainments of the "Human Vehicle" to progress to the "Great Vehicle". ${ }^{34}$

Taixu thus identified modernity as the period of the Final dharma and the "Human Vehicle" the expedient (upayya) teaching for this era. It is not coincidental that Taixu equated the age of modernity in secular history to the period of mofa in Buddhist history as previously indicated, mofa was introduced in the medieval period in connection with state persecution of Buddhists, so that the association would have appeared natural given the threats the state posed to the religion in early modern China. In pre-modern usages, the "Human Vehicle" and the "Heavenly Vehicle" are lower teachings emphasizing the accumulation of good karma toward rebirth either as human or god. But in Taixu's usage, "Heavenly Vehicle" refers specifically to otherworldly Pure Lands and Esoteric Buddhist paradises. Taixu was convinced that the "Lesser Vehicle" (to which the śrävaka Vehicle belongs) and the "Heavenly Vehicle" are no longer attractive to the modern world, since practices of the "Lesser Vehicle" come across in the modern era as negative and escapist, and those of the "Heavenly Vehicle" as superstitious. ${ }^{35}$ In other words, Taixu classified Buddhist teachings and practices with the goal to subordinate, or even exclude, those Buddhist elements that would potentially subject Buddhism to antireligious charges from intellectual and political thinkers in his day.

Since the core of the "Human Vehicle" really lies in the moral practices of the five precepts and ten virtuous deeds, its ethical thrust

34 Vol. 7 of Taixu's Complete Writings presents each type of teaching according to this threefold division.

35 The dangers of these two vehicles parallel the problems he perceived in Chinese Buddhism of his times. 
makes the "Human Vehicle," or "Buddhism for Human Life" (Chin. rensheng fojiao), the most conducive teaching for a modern world that prized pragmatism, rationality, and scientific objectivity. ${ }^{36}$ For Taixu, the ethical foundation of the "Human Vehicle" can transform this world into a "Pure Land for Humanity" (Chin. renjian jingtu), a social utopia in which each individual serves and benefits one's community and nation. ${ }^{37}$ Within this framework, the place to inaugurate the bodhisattva path is the "Human Vehicle," the teachings of which can lead directly to the "Great Vehicle" (Mahāyāna) and ultimately "buddhahood". Taixu referred to this bodhisattva paradigm as the "bodhisattva of Humanity" (Chin. renjian pusa), who is profoundly engaged with society and renders altruistic service to society as bodhisattva practices.

The ethical orientation of the "Human Vehicle" is essentially a social one in Taixu's view. It is perhaps intentional that the emphasis on humanism corresponds to the ideas of Western philosophers like Bertrand Russell and John Dewey. Moreover, the roots of humanist thinking can be traced to the early Chinese concept of "humanness" (Chin. ren) in Confucian thought, which located human cultivation within the context of human relationships in the social realm..$^{38}$ The concept of "humanness" is fundamental to the Confucian rendition of the ethic of "reciprocity" (Chin. shu) which states: "Do not impose on others what you do not want to be done to one-

36 The five precepts prescribe abstinence from killing, stealing, sexual misconduct, and imbibing intoxicants. The ten virtuous deeds are divided into three physical actions (not killing, not stealing, and not engaging in sexual misconduct); four verbal deeds (not lying, not backbiting, not speaking evil words, and not engaging in frivolous speech); and three mental actions (lack of greed, anger, and deviant views).

37 See his 1930 lecture "Establishing an Earthly Pure Land" (Chin. Jianshe renjian jingtu lun), Yinshun 1998, vol. 14, pp. 431-456.

38 The Chinese character for ren combines the radical for "person" with the number two; as such, the character aptly signifies the meaning, that is, the common ground of humanity shared by two persons. Many of the important virtues ("filial piety" or chin. xiao, "reciprocity" or chin. shu, "patriotism" or chin. zhong) which the Analects exalts are basically founded on ren, and may even be viewed as the concrete manifestation of ren within a particular familial or social relation. 
self". ${ }^{39}$ The practice of "humanness" thus distinguishes human from brutish and other non-human behavior, and is therefore reiterated as a defining trait of humanity. ${ }^{40}$ The innateness of "humanness" made the realization of humanism always theoretically possible. Thus Taixu's teaching of "Buddhism for Human Life" effectively reoriented Buddhism toward the new intellectual trends of modernity while still preserving continuities with traditional Chinese morality.

Ultimately, Taixu's progressive reforms aimed to produce a class of elite monastic leaders who, with their new learning and skills, would be best able to represent the religion, argue for and demonstrate its continued relevance in modern society. Embracing the tenets of Buddhism for the Human Life, these elitist sangha would be deeply engaged in daily society where they would provide social leadership for an increasingly learned laity.

\section{Buddhist Responses: Spiritual Cultivation and Restoring Tradition}

Besides the modernist, progressive approach, another strain of Buddhist responses approached the mounting religious crisis in the Qing-Republican period through a discourse of traditional practices and teachings often pared down to one particular method, the choice of which varied for each proponent. This category is largely made up of eminent monks, all of whom had claims to traditionally constituted training and spiritual realization, which earned them the deep respect of both lay and monastic communities. Among them the most prominent figures included the Chan master Xuyun (18401959), the Pure Land master Yinguang (1861-1940), and the vinaya master Hongyi (1880-1942). For Yinguang, Pure Land practice was the "singleminded recollection of the Buddha" (Chin. yixin nianfo); for Xuyun, Chan practice was the silent contemplation of "Who is the one recollecting the Buddha?" (Chin. nianfo shi shui). ${ }^{41}$ For Hongyi, rigorous observance of the monastic discipline was his criti-

39 Analects 12.2 and 15.23.

40 Comparable, for instance, to Epicureanism in ancient Greece, which extended brotherly love to embrace all humankind, manifesting in a love of the human race known as philanthropia.

41 For Yinguang's Pure Land method, see Jiang 1998, pp. 417-427. 
cal practice. It should be noted that like other periods in Chinese Buddhist history, the Qing-Republican eminent practitioners were syncretic in their religious observances; Xuyun and Yinguang, for instance, drew on and combined both Pure Land recitation and Chan meditation into their practice.

Unlike the progressive intellectuals who promoted worldly engagement and sought to "modernize" Buddhism with new knowledge and resources coming from outside of China, eminent renunciate monks adamantly insisted on returning to "tradition" and steadfastly reiterated how traditional Buddhist teachings and practices still had a place within the fast changing society and historical circumstances. Monasticism was still at the core of these visions, although they were adapted to an expanding laity who usually congregated around and relied on distinguished monastic practitioners for teachings and guidance. These visions rhetorically endorsed the traditional Buddhist rejection of the world that was the basis for monasticism. Although it is tempting to polarize the two groups into progressive versus conservative, it should also be noted that the seemingly "conservative" approach did not totally reject modern innovations and changes, despite its strong rhetoric on the preservation of "tradition". Despite their rhetoric of world withdrawal, they participated, for instance, in founding national Buddhist associations which provided a forum for safeguarding Buddhist interests and lobbying against those governmental policies that violated Buddhist rights. Some of these monks also endorsed and participated in sangha educational reforms.

Through his life and work the eminent monk Xuyun embodied the range of diverse activities undertaken by members of this group. A salient component of Xuyun's contribution is his restoration of dilapidated monasteries during this critical period of history. Besides the natural toll of time, the protracted borrowing and confiscation for state use, as well as the consecutive wars beginning from the late Qing, meant that the monasteries and temples endured much damage and urgently required repairs or even full scale restoration. Xuyun's first major restoration work happened in 1904 when he was visiting at Jizu Mountain (Chin. Jizu shan, "Cock's Foot Mountain") in northern Yunnan Province. At that time, all the temples and monasteries had become hereditary temples that were passed on by individual monks in the same lineage; the big public monasteries, traditionally regarded as the common 
property of all the saigha, no longer existed so that pilgrims had no place to stop and rest for the night. To remedy the problem Xuyun tried to build a shelter for the pilgrims, but the hereditary temples vehemently opposed the plan. Eventually with help from the laity in Dali, including some high-ranking officials, Xuyun was able to obtain rights to a ruined temple, the Boyu Hermitage (Chin. Boyu an, "Alms Bowl Hermitage"), which he began to restore. On completing the restoration, he opened the temple's doors to pilgrims who were welcomed to take shelter there for the night. He further drew up a code of rules, instituted meditation, delivered sütra lectures, and held an ordination ceremony for about seven hundred postulants. ${ }^{42}$

The struggles between the hereditary and public monasteries was one of the religious institutional problems which changes in state policies on monastery landholdings in the Qing-Republican period aggravated. Due to the lack of state protection, as well as the widespread mobility within monastic communities on account of the constant warfare and impoverished conditions, numerous public monasteries had fallen into hard times and were no longer able to sustain communal life, so that opportunist abbots and other individuals in the community, looking to acquire property rights during the uncertain economic and political times, usurped the rights to these public religious properties and transformed them into hereditary temples. As Xuyun's biography reveals, the state of Buddhist institutions was an acutely sore point for this eminent monk who associated the golden age of Buddhism with the flourishing of public monasteries which functioned as major centers of monastic training and religious practice, or even great academies of Buddhist learning. In this respect his views differed substantially from his contemporary Taixu who strongly advocated restructuring traditional monastic education in alignment with the modernization (mostly Westernization) taking place in secular education.

The next restoration project was the Huating Monastery (Chin. Huating si, "Floral Pavilion Monastery") in the Western Hills of Kunming (capital of Yunnan Province) in the year 1920. The resi-

42 See the 65th year (1904/05) of his biography (Luk 1988, pp. 54-58). For the orginal Chinese biography, see http://www.jindingsi. com/text/xuyunheshangnianpu.htm. 
dent monks of this monastery were planning to sell the dilapidated monastery to Europeans who had the desire to renovate and convert it into some kind of club. It was again Xuyun's intervention that convinced the local authorities to preserve and restore the Buddhist site. The officials agreed and appointed Xuyun as the abbot to oversee the restoration, a position he accepted. ${ }^{43}$ After its restoration, he renamed the monastery from Huating Monastery to Yunqi Monastery (Chin. Yunqi si, "Clouds Perching Monastery") in honor of the great Ming monk, Yunqi Zhuhong (1535-1615), who promoted the amalgamation of Chan and Pure Land practices at the original Yunqi Monastery in Hangzhou (Zhejiang Province). Other major restoration projects Xuyun supervised included the Gushan Monastery (Chin. Gushan si, "Drum Mountain Monastery") in Fujian Province, the site of the master's ordination. Here he restored not only the physical environment, but also its former rigor and moral character; he instituted a seminary for ordained monks and converted it back to its original status as a public monastery and implemented rigorous discipline. In short he frequently extended the task of material refurbishing to further encompass institutional reform.

But his most outstanding restoration projects are indubitably the Nanhua Monastery (Chin. Nanhua si, "Southern Floral Monastery") and Yunmen Monastery (Chin. Yunmen si, "The Gate of Clouds Monastery") both major Buddhist sites in the Chan lineage which are located in Guangdong Province. The Nanhua Monastery was where the famous sixth patriarch, Huineng (638-713), had lived during the Tang period and where his relic body had been enshrined until then. It was last restored by the Ming monk Hanshan Deqing (1546-1623) in the early seventeenth century, but had once again fallen into ruins. Another major project, one of Xuyun's last restoration works, was the Yunmen Monastery, the seat of the Yunmen Chan Buddhism, at Mount Yunmen, also in Guangdong Province. When he undertook the rebuilding of Yunmen Monastery (19441945), Xuyun was already 105 years old. This massive rebuilding involved the cooperation of several networks from the local patrons and monastic communities to the secular and religious governing officials, at times extending to overseas communities. Moreover, his

43 Luk 1988, p. 101. See his 81st year (1920/21). 
biography records his receiving patronage from Chinese immigrants abroad in places such as Burma, Hong Kong, and Singapore. In other words, Xuyun was hardly reclusive, but actively traveled and interacted with domestic and international Chinese Buddhist communities to raise funds for his restoration work. As his biography suggests, wherever he went, he taught sütras, administered precepts, converted lay followers, and set up lay associations. Moreover, under the rubric of restoration projects, he also revitalized monastic training centers. 44

Xuyun's life also demonstrates how eminent Buddhists deployed religious practices in response to political violations of religious rights during the Republican period. Given Xuyun's standing and his close ties with officials in the government, Xuyun often became a major negotiator and spokesman for local Buddhist communities whenever their religious rights were threatened. In this vein, when the revolutionary army marched from Wuchang to Yunnan Province in 1912, Li Genyuan, one of the commanding officials, issued a warrant for the arrest of the renowned Xuyun who, instead of attempting to escape, stayed to confront the commander. Xuyun convinced Li through his teachings so that the latter withdrew his armies and stopped demolishing monasteries in the region. Subsequently $\mathrm{Li}$ even attended vegetarian feasts at the monasteries. ${ }^{45}$ This was only one of several instances whereby Xuyun asserted considerable sway over potential enemies of the religion, so much so that in submitting to his holy charisma, they became patrons of the faith.

After rebuilding the Nanhua Monastery in northern Guangdong Province, the Sino-Japanese War broke out. The editor for Xuyun's biography inserts a description of an incident during this war at Nanhua Monastery:

[...] The Japanese intelligence learned that the temple was used as a meeting-place for Chinese officials. In the seventh month, when a large number gathered there, eight enemy bombers came and circled over it. The master knew of their intention and ordered the monks to return to their dormitories. After all the guests had taken refuge in the Hall of the Sixth Patriarch, the Master went to the main hall, where he burned incense and sat in

44 For example, at the Nanhua Monastery, he helped set up a monastic discipline for novices. See his 104th year (Luk 1988, p. 129).

45 See his 72nd year (Luk 1988, pp. 86-88). 
meditation. A plane dived, dropping a large bomb which fell in a grove on the river bank outside the monastery without causing damage. The bombers returned and circled over it when suddenly, two of them collided and crashed to the ground at Ma-ba, some ten miles to the West. Both planes were destroyed with their pilots and gunners. Since then the enemy planes dared not come near the monastery and always avoided flying over it on their bombing missions to the hinterland. 46

The account shows that Xuyun deployed meditation - which for him meant "recollecting the Buddha" (Chin. nianfo) - as a means to achieve singularity in mental focus. Renowned practitioners like Xuyun evidently believed in the "otherworldly" powers of cultivation. In responding to the exigencies of war and political oppressions, his actions reflected the traditional Chinese Buddhist cosmology based on the concept of ganying, a causal theory of stimulus (Chin. gan) and response (Chin. ying). A synthesis of indigenous Chinese cosmology and Buddhist karmic causation, ganying explains how the power of spiritual action brings about the miracle of religious protection. ${ }^{47}$ Moreover, by virtue of his holy attainments, Xuyun provided miraculous protection for the local community, just as the state had always counted on the supernatural powers of Buddhist saints and monks to render protection for the court and the nation at war.

Xuyun also experienced the more intense religious persecution under Communist rule. When he was 112 years old (1951/52) and living at Yunmen Monastery, a hundred Communists seized the monastery and ransacked the place for two days: 48

46 Luk 1988, p. 128.

47 In addition, from the Chinese Buddhist perspective, a "miraculous experience" is in some sense always bound to the principle of moral causation insofar as the spiritual efficacy or "numinous verification" (Chin. lingyan) - however strange or inexplicable at first glance is always caused, so to speak, through the observance of some form of religious practice, such as by the worship of a deity, scripture, a holy person or object. Several scholars have discussed the Chinese Buddhist concept of ganying and similar usages; see Birnbaum 1986, p. 137; Kieschnick 1997, pp. 97-101.

48 Although the biographical text only calls them "bad people," it is clear from the context that this was probably a Communist inquisition. In the introduction to the English translation, the editor Richard Huhn also refers to them as Communist cadres (Luk 1988, p. xiv). 
[...] They also put the registers, documents, correspondence and all the Master's manuscripts of explanations and commentaries on the sütras and his recorded sayings during a whole century - in gunny bags which they carried away. They then accused the community of all sorts of crimes, but in reality they had wrongly believed groundless rumors that there were arms, ammunition, radio transmitters, gold bars and silver bullion hidden in the monastery $[\ldots]^{49}$

As the search did not yield any result, the thugs roughed up the resident monks and then isolated Xuyun for interrogation. They locked him up, starved him, refused him drink, and hammered him with steel batons.

He was interrogated while being attacked, but sat in the meditation posture to enter the state of dhyana. As the blows rained down mercilessly, he closed his eyes and mouth and seemed to be in the state of samadhi. That day they beat him brutally four times [...] A little later [...] the Master's attendants carried him to a bed and helped him sit in the meditation posture. ${ }^{50}$

Xuyun survived two rounds of such brutal beatings and lived to describe to his disciples his visionary encounter with the Future Buddha Maitreya in the Tusita heaven during one of these semiunconscious states following the harassment. The lives and spiritual attainments of eminent teachers like Xuyun served as critical sources of inspiration for Buddhists during the troubled times of political oppression in the modernization of China. They were beacons who embodied the resilience and strength of the "tradition" in difficult times.

\section{Diverging Paradigms, Converging Paths?}

On the surface there exist stark contrasts between the two sets of Buddhist responses to political oppression that took shape in early modern China. In fact, the seemingly conservative Buddhist monks were quite often openly critical and skeptical of the progressive Buddhist reformers, and there are reports of Yinguang frowning on Taixu's engagement with society. ${ }^{51}$ Progressive Buddhist intellectuals like Taixu advocated doctrinal and institutional reforms to modernize Buddhism in the hope that the religion would survive

49 Luk 1988, pp. 138-139.

50 Ibid., p. 139. 
the process of China's modernization without being discarded as irredeemably obsolete. They enthusiastically incorporated modern knowledge and resources from the West and Japan into their visions of a new Buddhism, and often presented Buddhism as an ideal candidate for representing Chinese society in global exchanges of thought and culture. It is no coincidence that for the latter half of his life Taixu participated actively in global conversations, allied himself with international forces, and visited different countries in the West and Asia, so much so that he earned himself the (somewhat disdainful) reputation of a "globe-trotting" monk. 52 As Taixu's career demonstrated, these progressive Buddhist intellectuals often derived their original inspiration from the revolutionary thought in secular politics that would eventually topple over the age-old system of imperial rule and traditional culture with Western notions of democracy, liberalism, and pragmatism. For example, it was contact with Sun Zhongshan's political ideology which persuaded Taixu that "Buddhism would need to undergo a revolution in the same way as China's political revolution". ${ }^{53}$ However, ultimately, Taixu returned to the Buddhist

51 Pittman (2001, p. 237) cited oral interviews with Yinguang he had gathered from different sources, in all of which Yinguang seemed to have expressed dissatisfaction with Taixu and his companions.

52 For his own descriptions of his travels to England, France, and Germany, see Taixu 1978, pp. 1-91.

53 Yinshun 1998, vol. 29, p. 192. Taixu was subsequently introduced to Sun Zhongshan's Revolutionary Alliance and his "Three Principles of the People" (Chin. sanmin zhuyi), and in 1910 would become implicated in revolutionary activities to overthrow the Qing dynasty. The "Three Principles" are "People's Welfare" or "Government for the People" (Chin. minsheng), "People's Rights" or "Government by the People," (Chin. minquan), and "People's Relation" or "Government of the People" (Chin. minzu). People's Welfare refers to social welfare and is sometimes identified with socialism; Sun, under the influence of the American thinker Henry George, understood it as an industrial economy and equality of land holdings for the Chinese peasant farmers. People's Rights really refers to democracy, which for Sun, represented a Western constitutional government. People's Relation is simply nationalism which, for Sun, meant freedom from imperialist domination, the need to foster "civic-nationalism" as opposed to "ethnic-nationalism". 
sources for inspiration, and introduced a form of modern Buddhism, the "Buddhism of Human Life," which deliberately reinterpreted traditional elements to make them compatible with modernist insistence on rationality, empirical objectivity, and an explicit humanitarian thrust, just as their Tang, Song, and Ming predecessors too had reimagined Buddhism for their historical times. In other words, Taixu and the progressive Buddhist intellectuals hardly discarded Buddhist traditions, but instead reimagined them for the age of modernity. In terms of relations with the state, the modernist, progressive visionaries promoted active Buddhist participation in the secular spheres of economics, politics, and society. The strategy was to present the sangha as no longer reclusive and otherworldly, but as useful agents in modern Chinese society who could make invaluable social contributions as community leaders in education and social welfare.

On the other hand, the seemingly more conservative, practiceoriented eminent monks portrayed themselves as restoring and perpetuating "tradition" during the troubled social and political times. But "tradition" here refers really to the teachings and practices of the four major Buddhist reformers in the Ming period (1368-1644) like Hanshan Deqing, Ouyi Zhixu (1599-1655), Yunqi Zhuhong, and Zibo Zhenke (1543-1603). ${ }^{54}$ Both Hanshan and Zhuhong were important proponents who synthetically linked Chan meditation to the Pure Land practice of "recollecting the Buddha" (Chin. nianfo) through the "one mind" (Chin. yixin) - an innovative amalgamation which both Republican monks Xuyun and Yinguang adopted and promulgated. ${ }^{55}$ Zhuhong, in addition, was particularly renowned for his reform of monasticism, something with which $\mathrm{Xu}-$ yun was also engaged, in addition to his physical restoration of dilapidated great monasteries. Zibo was known for his numerous restorations of Buddhist sites, again a practice that was widely adopted in the Republican period, Xuyun being a stellar example. In other words, this cluster of Republican eminent practitioners styled them-

54 On Buddhist reforms in the Ming period, see Jiang (2005).

55 For Hanshan's understanding of Chan and Pure Land, see Hsu 1970, pp. 127-136; for Zhuhong's interpretation of the one mind, see Hurvitz 1970. For a book-length study on Zhuhong, see Yü 1981. For an overview of Ming Buddhism with a special focus on Zhixi, see Shengyan 1975. 
selves as "transmitters of tradition," thereby placing their endeavors within a distinct historical trajectory that Confucius began in the Analects with an exhortation to return to the golden era of early Zhou Dynasty. The quest to recover a lost golden era is a familiar, recurrent theme in religious history and in the guise of reinstating "ancient tradition" religious innovations are introduced, authorized, and allowed to flourish. 56

Although Republican monks like Xuyun and Yinguang rhetorically presented themselves as restoring traditional monasticism - both its physical architecture and moral fabric - as a lifestyle understood to transcend the secular world, particularly familial, political, and social ties, the historical realities were far more complex. The Chinese term for becoming ordained as a bhiksu or monk is chujia, which literally means "leaving the household," that is, withdrawal from the affairs of the world. From the perspective of Buddhist relations with the state, this rhetorical assertion of the transcendence of the monastic vocation is double-edged. On the one hand, since the saingha is withdrawn from society, they could be deemed to have little impact and therefore pose no threat to the central government. On the other hand, given that its lifestyle and values are deliberately counter to normative society, its very existence is a powerful critique and always potentially a threat to political stability. As previously discussed, Xuyun was hardly a naive spokesman of the "tradition," but evidently capitalized on both these strands in his relations with the state during the tumultuous times. He certainly withdrew from the secular world insofar as he remained singularly focused on Buddhist propagation and practice, and functioned mostly among Buddhist circles. However, he repeatedly employed his moral and religious charisma to challenge government officials and military bandits so as to protect local

56 The quest for the pristine origin is found in different aspects of religion. Mircea Eliade (1907-1986), the famous Romanian historian of religion, called attention to this theme in myth and ritual by coining the phrase, "the eternal return". By this, he was pointing to an almost compulsive urge to return to the mythical age, to become so to say contemporary with the events described in one's myths - a belief often expressed in religious behavior, particularly through ritual (see Eliade 1971). Eliade's model and the quest for origin in religion have been critiqued in more recent scholarship; see Masuzawa 1993. 
communities and his religion during the civil wars and the Japanese invasion. Given his numerous ties to official patrons, it is not surprising that Xuyun emerged as a major negotiator for Buddhist rights playing a role reminiscent of the fourth-century aristocratic monk Huiyuan who was mentioned at the beginning of this essay. Interspersed throughout his biography are anecdotes of how $\mathrm{Xu}-$ yun's religious attainments so impressed potential military or official persecutors of the religion that they spared the Buddhist monasteries and local communities from further violation of Buddhist properties and religious rights.

Moreover, in real life, eminent monks like Xuyun actually engaged in a broad spectrum of activities that embraced worldly participation. Like Taixu, Xuyun had an amazingly extensive network of Buddhist patronage and support domestically in China as well as internationally around Asia. His international activities, however, were always couched within the traditional Buddhist framework and circuits of cleric-laity patronage and instruction. Eminent practitioners like Xuyun also actively participated in Buddhist reformative activities such as revitalizing sangha education, forming national Buddhist associations, and establishing Buddhist or secular schools, and social charities on the monastery's premises. Like the progressive reformers, the more conservative wing was also very active in helping to train a broadly based lay movement to which the saingha could look for support, patronage, and protection. Educating the laity was deemed especially important in a time when Buddhist rights, especially those of the monastic communities, were frequently transgressed upon by the state. In other words, these eminent practitioner monks were never rigorously conservative, or even totally reclusive.

The progressive modernists and traditional conservatives were in short never really as sharply polarized as modern scholarship would have us believe. ${ }^{57}$ Rather than an irreconcilable dichotomy,

57 Studying Pure Land in Taiwanese Buddhism, Charles Jones (2003, p. 128) sets up a dichotomy between the modernists and the denouncers of modernist interpretations, tracing them back to early twentiethcentury figures like Taixu and Yinguang. He bases this approach on Welch's (1968) characterization. There are indeed some salient distinctions, for example, in the academic study of Buddhism: the modernist group embraced scholarship while the conservative traditional 
there existed a continuum of voices which fluidly overlapped in their concerns, practices, and enterprises to secure the survival of Buddhism during the social and political transitions in early modern China. Both these forms of Buddhist responses are still very much alive in Chinese-speaking Buddhist communities. In Taiwan, Buddhist modernism has been recreated for the Taiwanese audience and under the name of "Humanistic Buddhism" (Chin. renjian fojiao) is now accepted as one of the mainstream expressions of Buddhism. ${ }^{58}$ In mainland China, the two groups of Buddhist responses were unable to halt the destruction to their religion under Communist rule, particularly during the Cultural Revolution. ${ }^{59}$ Nonetheless they remained important sources of inspiration, particularly in the contemporary scene, where a robust resurgence of Buddhism has taken place in recent decades. Supported in part by the central government, this revitalization of Buddhism is organized around the two different Buddhist paradigms that first arose in the Qing-Republican period. ${ }^{60} \mathrm{How}$ these paradigms may be used to apprehend modern concepts like religious rights and human rights is a topic that awaits further ethnographic research.

expression was quite often anti-intellectual and adhered to traditional sūtra and commentarial studies. See Jones 1999, p. 124.

58 Renjian fojiao is a teaching espoused by Yinshun (1906-2005), one of Taixu's monastic students, who fled from Communist China and finally settled down in Taiwan. Deriving inspiration from Taixu's rensheng fojiao, Yinshun introduced the concept of renjian fojiao, so coined to highlight the human realm as opposed to the other realms of rebirth. The rise of "Humanistic Buddhism" (renjian fojiao) is linked to the flowering of independent Buddhist organizations which flourished in the late twentieth century challenging the hegemony of the Buddhist Association of the Republic of China, after the lifting of military law in 1987. They yield new, divergent formulae for adherents to realize the bodhisattva path right here and now by creating a better society for all beings. The most powerful Taiwanese Buddhist groups, "Compassionate Relief" (Chin. Ciji, more commonly spelled Tzu Chi), "Dharma Drum Mountain" (Chin. Fagushan), and "Buddha Light Mountain" (Chin. Foguangshan) all present themselves as renjian fojiao.

59 For Buddhism under the Communist rule, see Welch 1972.

60 See Zhe 2004. 


\section{List of Chinese Terms}

biguan 閉關

Boyu an 缽孟庵

chujia出家

Ciji 慈濟

conglin 丵林

daoguan 道官

feifo 廢佛

Fagushan 法鼓山

Fofa jiushi zhijingshen 佛法 救世之精神

Foguangshan 佛光山

Fojiao xiejin hui 佛教協進會 Foxue yanjiuhui 佛學研究會 fosi 佛寺

foxue 佛學

foxue yuan 佛學院

Fozu tongji 佛祖統紀

Fuzhou chuanzheng xuetang 福州船政學堂

ganying 感應

guan 觀

Guangxiao si 廣孝寺

Guanli simiao tiaoli 管理寺廟 條例

Hanshan Deqing 慜山德清 Hong Xiuquan 洪秀全 Hongming ji 弘明集

Hongyi 弘-

Huating si 華亭寺

Huineng 慧能 (also 惠能)

Jiang jing 講經

Jianshe renjian jingtu lun 建 設人間淨土論

Jinling kejing chu 金凌刻經 處

Jinshan si 金山寺 jiu shi 救世

Jizu shan 雞足山
Kaifu si 開福寺

Kang Youwei 康有為

Gushan si 鼓山寺

Li Genyuan 李根源

Liang Qichao 梁啟超

lingyan 靈驗

Longhua si 龍華寺

minquan 民權

minsheng 民生

minzu 民族

miefa 滅佛

mofa 末法

Nanhua si 南華寺

nianfo 念佛

nianfo shi shui 念佛是誰

Ouyi Zhixu 蕅益智旭

panjiao 判教

Putong seng xuetang 普通僧學

堂

Putuo shan 普陀山

Puyi 溥儀

Quanxue pian 勸學篇 renjian fojiao 人間佛教 renjianjingtu 人間淨土 renjian pusa 人間菩薩 rensheng 人乘

Rensheng de fojiao 人生的佛教 rensheng fojiao 人生佛教

Rensheng fojiao de shuoming 人

生佛教的說明

Renxue 仁學

sanmin zhuyi 三民主義

sanwu yizong fa'nan 三武一宗法

難

Seng shifan xuetang 僧師範學 堂

Seng[qie] jiaoyu hui 僧[伽]教育 會 
Sengyou 僧祐

Shamen bujing wangzhe lun 沙門不敬王者論

shengwen sheng 聲聞乘

Shizong 世宗

si dafa'nan 四大法難

$s h u$ 恕

Sun Zhongshan 孫中山

Taiping 太平

Taixu 太虚

Tan Sitong 譚嗣同

Tianning si 天寧寺

tiansheng 天乘

Wudi 武帝

Wuzong 武宗

xiangfa 像法

xiao 孝

Xiuzheng guanli simiao tiaoli 修正管理寺廟條例 xuetang 學堂
Xuyun 虛雲

$\mathrm{Yan} F u$ 嚴復

Yang Wenhui 楊文會

Yinguang 印光

Yinshun 印順

yixin nianfo 一心念佛

Yuan Shikai 袁世凱

Yunmen si 雲門寺

Yunqi Zhuhong 雲棲袾宏

Yunqi si 雲棲寺

Zhang Zhidong 張之洞

Zhang Taiyan 章太炎

zhengfa 正法

Zibo Zhenke 紫柏真可

Zhihuanjingshe 祗洹精捨

Zhipan 志盤

zhong 忠

Zhonghua fojiao zonghui 中華 佛教總會 
